\title{
DEMOCRATIC VALUES, PEDAGOGY AND HENRY GIROUX
}

\begin{abstract}
Mahadev Devkota *
Abstract

The present study" Democratic values, pedagogy and Henry Giroux "is an attempt to explore the democratic values in the pedagogy particularly in critical pedagogy in regard to Henry Giroux's perspective. This qualitative research employed descriptive methodology along with using relevant secondary sources for the claim, supporting reasons, and finally develop argumentation based on themes since it is written in the form of argumentation. The finding of this study shows that critical pedagogy as a wider democratic project plays an amicable role to impart democratic values across the country including the classroom practices. However, this relatively new paradigm is also not free from criticism. It is criticized as impractical, misleading and conflict-oriented rather than actually solving the problem.
\end{abstract}

Key words: Democratic values, critical pedagogy, Henry Giroux, student-centered pedagogy, neoliberal

\section{Introduction}

Democratization has become a catchword since thedemolition of the Berlin Wall which ends the polarizationof the world order into a new one (Tabulawa, 2003).With the growth of democratic practices across the globe, democratic values or ideals were kept into consideration. Macfarlane (2019) identified numerous democratic values such as truth, honesty, equality, justices, liberty, emancipation, selfcritiquing and tolerance, respect the distinct voices, creatingan atmosphere for intellectual liberation, the growth of learners' academic freedom and critical thinking skills. I believe that critical pedagogy plays a crucial role to establish democratic values in the society. Peters (2005)argued that Critical Pedagogy, an instructional method pioneered by Paulo Freire during 1970s aims to bring change in the field of academia and pedagogy as a wider project of democracy for the growth of democratic values, norms and dynamic citizenry helps to understand the relationship between knowledge, pedagogy and powerwas carried by Henry Giroux, Stanley Aronowitz and Peter McLaren to United States.Supporting this stance,Knight and Pearl (2000) argued that critical pedagogy had mingled democratic values such as inclusiveness, participatory decision-making process, equal rights, significant knowledge, nature of authority, and empowerment of the ignored, marginalized, and oppressed.However, academic values had dramatically changed into skills in the digital era, and in the current time,these institutions were shaped by the strong force of neo-liberalism to assistance the labor market (Macfarlane, 2019).The collaboration among democratic actors was essential to create a just and fair society so that they could investigate the world from the widerviewpoint, and critical pedagogy function as a significant instrument for reordering and transforming the social and cultural aspect of life to maintain democratic values (De Lissovoy, 2013).I believe democratic values are

* Mr Devkota is Lecturer of Madhyabindu Multiple Campus and M. Phil. Scholar of NOU. 
closely associated with critical pedagogy. Critical pedagogy not only refers to a close and depth study of a text, the advancement of critical literacy, promoting democratic value system, taking education as a powerful intervention technique in public life, connecting classroom practices to social transformation and the most perilous challenges were to safe academia and the pedagogy from the neoliberal market ideology such as privatiszation, imprisonment, consumerism, global standardization, obligation, and disciplinary practices of surveillance(Giroux \& Giroux, 2016).

Critical pedagogy accepted that the objective of education was not neutral and value-free rather ideological, dialectical, political, and performative, and most significantly it reflected how culture and educational practices were constructed and guided by the principle of open market (Denzin, 2009). However, Knight and Pearl (2000)argued that democratic education was only effective and efficient when it brought the common people into the mainstream politics by empowering through critical education and ability to make appropriate decisions for themselves and their community's prosperity, and also inspired all the stakeholders to actively participate to influence the policies and the path of education. In line, Suzani (2018)asserted that Freire utilized critical education skill as an instrument to uplift the condition of oppressed, unheard and silenced Brazilian farmers and taught them to use education as a means to enhance better future, and also opined that knowledge should always respect the needs, interests and curiosity of learners. However, Critical pedagogy believed that academic institutions preserved the ideology and vested interest of dominant class of society because such sites were the place of struggle among different interest groups, and should make students aware about the anti-democratic forces of society by empowering and revitalizing the human agency for just society (Giroux, 2004).Similarly, Giroux (2015)Critical pedagogy considered education as a means of intervention to make learners' capable and strong enough to combat against the deeply imbedded social injustices, inequality, discrimination, and exploitation to create social transformation, and also suggested all the learners should conscious about their rights, recognized dominant force of neoliberalism and most importantly understand that learning was not only the passive process of receiving knowledge. Furthermore, Fritch (2018)opined that instructors'accountabilityin critical pedagogy was to create conducive atmosphere where a students could keenlyexperience their own learning, learnt skills to become a all-time critical thinker and collaborator to construct knowledge, and also understand that both instructors and an act of teaching was not free from politics. Moreover, Giroux ( 2004 )argued that neoliberal ideology was not limited to academic institutions, teaching materials, evaluation system, however it operate din the broader area of social institutions such as commercials, popular culture, athletic, mass media, churches and networking of privilege, and most perilously it devalued the importance of social bonding, nationality, education and merely treated teaching-learning activities as a financial investment and a part of preparing future workforce.

The above literature emphasised that critical pedagogy contains the several democratic values such as inclusiveness, equality, justices, liberty, truth, 


\section{The Journal of Madhyabindu Multiple Campus, Vol. 6, No. 1, 2021}

tolerance, respect the differences, self-critiquing, honesty,emancipation, exercising intellectual freedom, and the empowerment of oppressed, ignored, misrepresented, and also inspire the learners to raise the voice against the deeply rooted social evils, established their own identity and act to change their destiny and their community's people. Likewise, some of the studies reported that teachers should act as an ambassador of academic institutions to rethink, reformulate, and challenge the suppressive and dominant ideology of global capitalism i.e. neoliberalism that limits all the stakeholders of the society are the mere puppet of the market economy. However, some other studies pointed out that the education system is not to produce docile, inactive, and passive people who are guided by the market ideology of profit and loss and also safe educators from being the corporate agents by making them thinkers not professional. Likewise, some studies focus on the collaboration of democratic actors to meet the broader project of democracy. Therefore, a study is needed to explore the importance of critical pedagogy to maintain democratic values and norms in society.

\section{The Democratization of Pedagogy}

Altinyelken (2015)in Turkey found that student-centered pedagogy (SCP) had played an amicable role to stimulate democratic values in the classroom. This is because SCP facilitated students' classroom contributio ncreating a conducive, childfriendly democratic environment of sharing diverse perspectives and communications dismantling the hierarchical authority of teachers and maintain equal locus of educators and learners for the construction of knowledge, and also taught wider understanding how social, political and cultural setting support or hinder such democratic values in the society. Moreover, a study conducted by (Sriprakash, 2010)in India argued that educators' greater dedication, devotion, and time was essential to implement childcentered pedagogies because this sorts of education policy demanded to use greater resources, democratic languages, individual evaluation profiles, educating parents and most importantly understanding specific material and institutional setting to ensure learnerfriendly quality education. Earlier, Rose (2005)argued that practicing true democracy required to implement the democratic pedagogy which only ensured academic, pleasant, democratic settings from the classroom across South Africa. He further suggested reading strategy to scaffold learners by selecting an appropriate textbook considering their interests and curiosity, creating preparation time before actual reading, suggesting them to find out key information from each paragraph, making the sentences, and finally concentrating on the mechanics of writing. Supporting this stance, MacMath (2008)opined that democratic pedagogy needed to follow Dewey's doctrine of all the human being particularly learners were morally equal, capable of intelligent, taking decent decisions, knowledgeable opinions, the capability to tackle any problems, and the skill to work collaboratively.He further emphasised instructors' sincere accountability to respect open dialogue and constructive feedbacks of students to enhance a democratic atmosphere. I believe that all the stakeholders of education are equally responsibleto refine classroom atmosphere, teachers'students' relation, teaching materials, teaching strategies, and as such to ensure democratic values and finally assistance the broader project of democracy in the country. 
Similarly, Schostak (2014)in Britain recommended cooperative school proposed by Dewey should act as a workshop for the growth of democratic values making the learners' voice heard, and instructors needed to be conscious about the unseen motive of the curriculum and introducing supersurveillance technologies to records human behaviors, disciplinary actions, other personal traits and information, such devices only promotes anti-democratic values making the teacher and learners mere puppet of the elite. Earlier, while talking about the areas of curriculum,

Knight and Pearl (2000)proposed curriculum ought to address the diverse problem areas such as violence, gender inequality, injustices, discrimination regarding race, class, ethnicity, backwardness, and sexually communicated disease. He further suggested learners should have given the training for better parenting, and need to reconstruct the school culture to establish democratic values. Moreover, Nick, S. (2010) argued that critical pedagogy facilitated the learners' engagement and construction of emancipatory and democratic knowledge critiquing the adverse impact of the neoliberal trend in education, and made learners equally aware to ponder on the catchy term like autonomy, accountability, and authority.

The above study reflects that studentcentered pedagogy is essential to promote democratic values in the classroom by creating an academic, pleasant, and conducive atmosphere, while selecting teaching materials students' interest and curiosity should be kept into consideration, facilitating open discussion, co-operation and raising voice against the super surveillance techniques, which are monitoring the people's minute traits and personal information.

\section{Critical Pedagogy and Henry Giroux}

McLaren and Giroux (1990)opined that critical pedagogy connected the entire education system with the social, economic and cultural aspects of the society. They further reported that critical pedagogy aims to redefine role of educators as a cultural agents and facilitated them to counter the dominant ideology related to elitist, racist, sexist and other assumptions reflecting the power imbalance, and contested interest of learners, teachers, parents, other associated stakeholder in regard to the achievement and delivery of knowledge. However, Saltman (2012)suggested to combat against the corporate school reform policy aims to substitute government-aided schools by privately-owned schools promoting academia as an industry following the terms and conditions of business, treating learners as consumers and knowledge as a product. He further requested those true educational reformist that it was a high time to reconsider the social, cultural, and political values and prepared to fight against the destructive corporate schools.In the same year, Henry Giroux in an interview with Michael A. Peters argued that leading market ideology snatched the entire social values, norms, tradition, community welfare, public accountability, human relation and the sacred nature of politics, and created an environment that thinking beyond such ideology was almost impossible. He further emphasised that in such vicious atmosphere universities had overlook their ethic to do with history, education, language, culture, civic well-being i.e. economic Darwinism was at the heart of each and every sector of human life (Peters, 2012). Furthermore, Giroux (2014) argued that neoliberal market ideology transformed the academic institutions into almost dead 


\section{The Journal of Madhyabindu Multiple Campus, Vol. 6, No. 1, 2021}

zones because they were unable to wage a war against the social evils such as poverty, hunger, prejudice, injustices, inequality, brutality, stateprotected crime, gradually increasing security budgets and most importantly it killed human creativity particularly educators and learners by changing educational organization as mere a place for training and evaluating the learners. He further opined that although America vowed functional democracy, where learners' critical thinking skills, imaginative faculty, public literacy, and social drive dysfunctional. These arguments, I believe that critical pedagogy especially learner-centered pedagogy is essential to uplift and challenged the anti-democratic force of neoliberalism.

Critical pedagogy is not beyond the criticism. There are several criticism under this pedagogy as it is misguiding and conflict-oriented pedagogy. For instance: David Hayes (2015) criticized the critical pedagogy as misguiding because it aimed to receive joy in confrontation and protection of own opinions, it simply tried to bring disparity among learners in the classroom however it might belongs to the same content. He further said that in such classroom, the teacher needed to enquire the students to clear about their position without understanding the things actually, and suggested non-critical thinking classroom only sharpened the leaners' imagination and claimed that it was greater to the critical one to maintain democratic norms and occupation. Similarly, Similarly, Wardekker and Miedema (2014) argued that critical pedagogy, though one of the significant approach in academic discourse lacked practical outcomes and suggested Vygotskian positions following discursive theory of identity was an appropriate ways for specifying the aims of education.
Earlier, Fobes and Kaufman (2008) revealed numerous problems in the implementation of critical pedagogy such as instructors-learners contradiction, ranking and evaluation system and learners' might feel uncomfortable with innovative style of pedagogy who used to in traditional model of teaching-learning activities, and most importantly how far educators were value-free in their profession, how fair learners were while working with teams and how successful both learners' and teachers' were to connect their previous experiences and understanding with curriculum to impart education.

\section{Conclusion}

Critical pedagogy, one of the wider project of democracy played a vital role to establish democratic value such as honesty, liberty, truth, equality, Justices, tolerance, self-critiquing, inclusiveness, participatory decision-making process, respect the diverse opinions, intellectual freedom, critical thinking skills, empowerment of marginalized, oppressed, and the cultivation of students' academic freedom. The majority of the studies emphasized that critical pedagogy was not simply transferring information and fact, it was a human experience and took it as an emancipatory and liberating tool to combat against the aforementioned social evils. Likewise, the researcher also stressed on the collaboration among diverse stakeholders to create a just and fair society. Likewise, some other studies reported that education was taken as an intervention tool to fulfill the promises of critical pedagogy respecting the learners' previous experiences and understanding connecting with the curriculum to face real-world challenges. However, some other studies figured out neoliberalism was the greatest challenge due to its destructive coverage in social, academic, economic, and other institutions. 
The large body of literature indicates that student-centered pedagogy plays a significant role to stimulate democratic values in the classroom creating a conducive learning atmosphere selecting appropriate learning materials keeping students' interest and curiosity into consideration. Some studies also suggested using Dewey co-operative school for the empowerment learners'and to know the hidden politics behind the curriculum. Some literature also suggested fighting against the corporate school was very difficult because they attacked government-aided school snatching remaining entire social, cultural, ethical values, norms, the tradition of the society, and promoting the privately-owned school as an industry following all the terms and conditions of the industry. Therefore, some other studies argued that academic institutions were almost dead zones changing themselves as training institutions for the workforce. However, few studies figured out that critical pedagogy was impractical, misguiding, and problemposing than addressing the actual problem in reality.

Therefore, the primary objective of this study is to explore the democratic values lies in the critical pedagogy in light of Henry Giroux. Thus, this study investigates entire aspects related to critical pedagogy beside its impractical and misguiding nature.

\section{References}

Altinyelken, H. K. (2015). Democratising Turkey through student-centred pedagogy: opportunities and pitfalls. Comparative Education, 51(4), 484-501. https://doi.org/10.1080/03050068.2015.1081794

De Lissovoy, N. (2013). Pedagogy in common: Democratic education in the global era. Educational Philosophy and Theory, 43(10), 1119-1134. https://doi.org/10.1111/j.1469-5812.2009.00630.x

Denzin, N. K. (2009). Critical pedagogy and democratic life or a radical democratic pedagogy. Cultural Studies "! Critical Methodologies, 9(3), 379-397. https://doi.org/10.1177/1532708609332607

Fobes, C., \& Kaufman, P. (2008). Critical pedagogy in the sociology classroom: Challenges and concerns. Teaching Sociology, 36, 26-33.

Fritch, M. E. (2018). Teaching as a political act: Critical pedagogy in library instruction. Educational Considerations, 44(1). https://doi.org/10.4148/0146-9282.1868

Giroux, H. A. (2014). When schools become dead zones of the imagination: A critical pedagogy manifesto. Policy Futures in Education, 12(4), 491-499. https://doi.org/10.2304/pfie.2014.12.4.491

Giroux, H. A. (2015). Critical pedagogy and the postmodern/modern divide: Towards a pedagogy of democratization. Teacher Education Quarterly, 31(1), 31-47. http://www.jstor.org/stable/23478412

Giroux, H. A. ( 2004 ). Public pedagogy and the politics of neo-liberalism: Making the political more pedagogical. Policy Futures in Education, 2. 
66 The Journal of Madhyabindu Multiple Campus, Vol. 6, No. 1, 2021

Giroux, H. A., \& Giroux, S. S. (2016). Challenging neoliberalism's new world order: The promise of critical pedagogy. Cultural Studies: Critical Methodologies, 6(1), 21-32.

https://doi.org/10.1177/1532708605282810

Knight, T., \& Pearl, A. (2000). Democratic education and critical pedagogy. The Urban Review, 32(3).

Macfarlane, B. J. (2019). Reclaiming democratic values in the future university. Philosophy and Theory in Higher Education, 1(3), 97-113. https://www.peterlang.com/fileasset/Journals/PTIHE032019

MacMath, S. (2008). Implementing a democratic pedagogy in the classroom: Putting Dewey into practice. Canadian Journal for New Scholars in Education, 1(1).

McLaren, P. L., \& Giroux, H. A. (1990). Critical pedagogy and rural education: A challenge from Poland. Peabody Journal of Education, 67(4), 154-165. https://doi.org/10.1080/01619569009538705

Peters, M. (2005). Critical pedagogy and the futures of critical theory (I. G. Zeev, Ed.). Faculty of Education, University of Haifa.

Peters, M. A. (2012). Henry Giroux on democracy unsettled: From critical pedagogy to the war on youth - An Interview. Policy Futures in Education, 10(6), 688-699. https://doi.org/10.2304/pfie.2012.10.6.688

Rose, D. (2005). Democratising the classroom: A literacy pedagogy for the new generation. Journal of Education and Practice.

Saltman, K. J. (2012). Why Henry Giroux's democratic pedagogy is crucial for confronting failed corporate school reform and how liberals like ravitch and darling-hammond are making things worse. Policy Futures in Education, 10(6), 674-687. https://doi.org/10.2304/pfie.2012.10.6.674

Schostak, J. (2014). Supersurveillance, democracy, and co-operation - the challenge for teachers. Asia-Pacific Journal of Teacher Education, 42(4), 324-336. https://doi.org/10.1080/1359866x.2014.956047

Sriprakash, A. (2010). Child-centred education and the promise of democratic learning: Pedagogic messages in rural Indian primary schools. International Journal of Educational Development, 30(3), 297-304. https://doi.org/10.1016/j.jjedudev.2009.11.010

Suzani, S. M. (2018). Implementing critical pedagogy in EFL contexts: closing the gap between theory and practice. Journal for Educators, Teachers and Trainers, 9(1).

Tabulawa, R. (2003). International aid agencies, learner-centred pedagogy and political democratisation: A critique. Comparative Education, 39(1), 7-26. https://doi.org/10.1080/03050060302559

Wardekker, W. L., \& Miedema, S. (2014). Critical pedagogy: An evaluation and a direction for reformulation. Curriculum Inquiry, 27(1), 45-61. https://doi.org/10.1080/03626784.1997.11075480 